\title{
Kebijakan Poros Maritim Jokowi dan Sinergitas Strategi Ekonomi dan Keamanan Laut Indonesia
}

\author{
M. Najeri Al Syahrin \\ Universitas Muhammadiyah Kalimantan Timur
}

\begin{abstract}
As a maritime country Indonesia has economic and security opportunities as a foundation for national development. The future of the Indonesian maritime is realized through the synergy between the economic and the security aspect. This article describes the importance of such synergies within the framework of the global maritime fulcrum. Economic development in this framework is realized through 'tol laut' and connectivity of goods and services throughout Indonesia. In terms of security issues, the combating of illegal fishing is a form of defense policy as well as effort to maintain Indonesia's territorial sovereignty. On one hand, this paper stresses the importance of economic development supported by defense and security stability. On the other hand, the development of defense posture requires a robust economic strength. Economy and security are two aspects that are inseparable and mutually supportive as an effort to realize the ideals of Indonesia as a global maritime fulcrum.
\end{abstract}

Keywords: Global maritime fulcrum, economic and security, 'tol laut', illegal fishing

\begin{abstract}
Abstrak
Sebagai negara maritim Indonesia memiliki peluang ekonomi dan keamanan sebagai tumpuan bagi pembangunan nasional. Masa depan kemaritiman Indonesia tersebut diwujudkan melalui sinergi antara aspek ekonomi dengan aspek keamanan. Artikel ini mendeskripsikan pentingnya sinergi tersebut dalam bingkai kebijakan Poros Maritim dunia. Pembangunan ekonomi dalam kerangka ini diwujudkan melalui 'tol laut' dan upaya konektivitas barang dan jasa ke seluruh kawasan Indonesia. Dalam hal isu keamanan, pemberantasan pencurian ikan merupakan bentuk kebijakan pertahanan sekaligus upaya untuk menjaga kedaulatan teritorial Indonesia. Di satu sisi, tulisan ini menekankan pentingnya pembangunan ekonomi yang didukung oleh stabilitas pertahanan dan keamanan. Di sisi lain, pembangunan kekuatan pertahanan membutuhkan kemampuan ekonomi yang kuat. Ekonomi dan keamanan merupakan dua aspek yang tidak terpisahkan dan saling mendukung sebagai upaya mewujudkan cita cita Indonesia sebagai negara maritim dunia.
\end{abstract}

Kata-kata kunci: Poros Maritim global, ekonomi dan keamanan, tol laut, pencurian ikan 


\section{Pendahuluan}

Indonesia memiliki potensi menjadi negara dengan ekonomi kelautan yang menjadi sumber kemakmuran bagi masyarakatnya. Sebagai negara kepulauan terbesar menjadikan Indonesia memiliki potensi maritim dalam berbagai bidang tidak hanya sebagai kawasan bioteknologi dan wisata kelautan, perairan laut dalam dan mineral kelautan, tetapi juga industri pelayaran dan pertahanan serta industri maritim dunia. Selain potensi sumber daya alam tersebut, Indonesia juga diuntungkan oleh lokasi teritorial yang strategis secara politik maupun ekonomi. Indonesia berada di daerah ekuator, antara benua Asia dan Australia yang secara langsung menghubungkan ekonomi negara-negara maju. Selain itu, Indonesia juga terletak di antara dua samudera, Pasifik dan Hindia yang menjadikan Indonesia menjadi kawasan penghubung antarnegara di kawasan Asia Timur dan Asia Tenggara serta Asia Selatan. Beberapa selat strategis lalu lintas maritim global juga berada di perairan Indonesia yakni Selat Malaka, Selat Sunda, Selat Lombok dan Selat Makasar (Chen in Chen, 2014: 68).

Posisi geostrategi dan geopolitis tersebut memberikan peluang Indonesia tidak hanya sebagai jalur ekonomi global tetapi juga jalur keamanan laut internasional sehingga menempatkan Indonesia memiliki keunggulan sekaligus ketergantungan yang tinggi terhadap bidang kelautan. Sangat logis jika kemudian, ekonomi kelautan (kemaritiman) dijadikan tumpuan bagi rancangan pembangunan ekonomi nasional melalui gagasan Poros Maritim dunia.

Joko Widodo (Jokowi) mencanangkan Indonesia sebagai Poros Maritim Dunia, dimana upaya tersebut dilakukan melalui pengembangan ekonomi berbasis maritim guna terciptanya kesejahteraan. Selama ini, Indonesia kehilangan banyak sekali peluang ekonomi. Lebih khusus, ide Poros Maritim ini merupakan upaya dari pemerintahan Jokowi untuk meningkatkan konektivitas dan keterjangkauan antarpulau di Indonesia. Tujuan akhir dari konektvitas ini adalah pemerataan pembangunan ekonomi dan terciptanya keamanan maritim di Indonesia. Gagasan Jokowi melalui Poros Maritim ini mencakup dua elemen dasar pembangunan, yaitu sebagai sebuah doktrin dan sebagai strategi pembangunan nasional. Gagasan komprehensif ini juga mencerminkan optimisme baru mengenai kebijakan arah masa depan Indonesia (Sukma, 2014).

Perkembangan sektor maritim nasional kini masih menemui beberapa kendala. Untuk menjadi sebuah negara maritim, Indonesia harus mampu mengoptimal $\neg$ kan wilayah laut sebagai basis pengembangan kekuatan mi $\neg$ liter sekaligus pertahanan, tidak hanya sebagai sentralitas ekonomi semata. Dengan demikian, diharapkan kemajuan sektor pertahanan maritim Indonesia akan mendukung ekonomi nasional, sehingga akhirnya mampu menciptakan stabilitas keamanan negara. Kesejahteraan ekonomi kelautan tidak akan bisa dicapai apabila tidak didukung oleh keamanan 
maritim. Begitupula sektor keamanan maritim, akan sulit dicapai apabila tidak terdapat kesejahteraan ekonomi. Upaya mengelola keamanan maritim merupakan kunci bagi negara untuk meningkatkan kesejahteraan dan pertumbuhan ekonomi. Aspek ekonomi dan keamanan dalam paradigma maritim merupakan hal yang berkaitan dan saling mendukung.

Melihat urgensi tersebut, tulisan ini mencoba memberikan gambaran tentang sinergitas kebijakan dan strategi dalam kebijakan Poros Maritim yang tidak hanya memiliki tujuan dalam kepentingan ekonomi tetapi juga terdapat kepentingan keamanan didalamnya. Argumentasi dasar tulisan ini adalah elaborasi aspek dasar keamanan dan ekonomi sehingga Poros Maritim bisa menjadi tumpuan dan harapan masa depan Indonesia. Setelah memberikan uraian tersebut, tulisan ini juga mendeskripsikan bagaimana strategi dan upaya pemerintahan Jokowi mewujudkan gagasan tersebut.

\section{Arti Penting Kebijakan Poros Maritim Indonesia}

Poros Maritim dunia merupakan konsep yang disampaikan oleh Presiden Jokowi dalam KTT Asia Timur pada 13 November 2014 di Nay Pyi Taw, Myanmar. Jokowi lebih jauh menguraikan doktrin tersebut dengan pembangunan infrastruktur tol laut, industri perkapalan dan pariwisata maritim serta penerapan diplomasi maritim, baik itu peningkatan kerja sama maupun penanganan konflik maritim, seperti pencurian ikan, pelanggaran kedaulatan, sengketa wilayah dan perompakan maritim. Penyampaian strategi nasional Jokowi dalam konferensi negara-negara Asia Timur tersebut mengindikasikan hal yang penting. Jokowi membawa pesan politik sekaligus pesan ekonomi bahwa bagi Indonesia, kawasan Asia Timur dan Asia Pasifik secara keseluruhan berperan penting bagi stabilitas keamanan dan ekonomi global.

Lingkungan strategis Asia Pasifik telah bertransformasi menjadi kawasan penting dalam percaturan politik global. Kekuatan utama di kawasan ini akan menjadi persaingan strategis berbagai kerja sama baik ekonomi maupun keamanan. Aktifnya Cina dalam kerja sama strategis dengan ASEAN dalam beberapa tahun terakhir dan kebijakan One Belt One Road yang 'mempersatukan' kawasan Eurasia merupakan bukti nyata transformasi ini. Di sisi lain, Amerika Serikat juga terus meningkatkan kehadiran dan pengaruhnya di kawasan ini melalui kebijakan Poros Pasifik pada masa Barack Obama dan kini pada masa Donald Trump, Amerika Serikat juga selalu melakukan berbagai kunjungan strategis dan kerja sama berbagai negara di kawasan Asia Pasifik (Gindarsah, 2014).

Pemahaman Presiden Jokowi terhadap posisi geostrategis dan geoekonomi Indonesia tersebut diwujudkan dalam kebijakan Poros Maritim yang merupakan langkah penting dalam upaya melakukan sinergitas strategi untuk meningkatkan ekonomi dan disisi yang lain juga 
secara langsung memperkuat pertahanan dan keamanan laut Indonesia. Pusat gravitasi geoekonomi dan geopolitik dunia telah bergeser dari Barat ke Timur, sehingga perlu bagi Jokowi untuk menunjukan bahwa Indonesia akan menjadi Poros Maritim dunia sekaligus sebagai bangsa bahari yang sejahtera dan berwibawa (Presiden RI, 2015). Kawasan maritim akan menjadi wilayah vital bagi kehidupan ekonomi global dan proyeksi kekuatan nasional kedepan. Sentralitas peran negara diharapkan akan terus hadir dalam kondisi ini (Goldrick, 2015).

Penyampaian ambisi Presiden Joko Widodo tentang kebijakan Poros Maritim ini sekaligus mewakili doktrin baru politik luar negeri Indonesia. Doktrin ini menunjukkan ekspansi signifikan dalam ambisi pertahanan luar negeri Indonesia khususnya dalam bidang maritim. Ekspansi tersebut tidak hanya untuk kawasan ASEAN saja tetapi meluas menuju kawasan Samudera Hindia dan Asia Pasifik (Agastia et al., 2015: 36). Sebagai sebuah doktrin politik luar negeri yang hasil akhirnya merupakan perwujudan kepentingan nasional maka penyampaian gagasan Poros Maritim Indonesia juga secara langsung sebagai sebuah doktrin keamanan nasional Indonesia. Jokowi berupaya memfokuskan kembali arah kebijakan luar negeri dan peran strategis Indonesia sebagai negara maritim serta sekaligus akan memperluas pengaruh Indonesia di luar 'kandang' kawasan ASEAN (Chen in Chen, 2014: 77).

Munculnya isu keamanan maritim diawali dengan pemahaman akan fungsi wilayah perairan yang strategis bagi kepentingan negaranegara di dunia. Wilayah maritim merupakan urat nadi utama interaksi ekonomi dan keamanan global, sehingga menjadikan keamanan maritim isu yang sangat krusial tidak hanya dilakukan oleh Indonesia saja tetapi juga negara lain. Pemahaman dan upaya mewujudkan wilayah laut sebagai sentralitas kebijakan diharapkan akan mampu mewujudkan stabilitas keamanan maritim dan kepentingan nasional sehingga berdampak pada pembangunan ekonomi dan kesejahteraan (Nugraha et al., 2016: 175).

Upaya tersebut diimplementasikan melalui perlindungan ekonomi lokal dengan melakukan investasi infrastruktur tol laut dan upaya memberantas penangkapan ikan ilegal. Konseptualisasi Jokowi tentang Indonesia sebagai negara Poros Maritim dunia selain sebagai proyeksi kebijakan maritim eksternal, juga pada dasarnya merupakan visi yang terfokus di dalam negeri terlebih dahulu. Harapannya adalah ketika permasalahan domestik dapat terselesaikan maka proyeksi sebagai negara Poros Maritim dunia akan dapat terwujud (Sambhi in Chen et al., 2014: 28).

Melalui strategi ini, Jokowi menekankan beberapa hal. Pertama, pembangunan ekonomi lokal dengan mendukung terwujudnya infrastruktur dalam memajukan perekonomian maritim Indonesia. Salah satu rencana pembangunan dalam menunjang poros ekonomi maritim 
adalah pembangunan tol laut. Dengan jumlah pulau yang sangat banyak yaitu 17.504 pulau, tentunya membutuhkan waktu yang tidak singkat untuk mengintegrasikan banyak pulau tersebut dalam kegiatan ekonomi (Presiden RI, 2015). Kedua, Jokowi ingin mempertegas bahwa identitas bangsa Indonesia adalah identitas maritim. Gagasan ini kemudian dikembangan menjadi doktrin keamanan maritim, bahwa Indonesia harus berdaulat di perairan lautnya dengan tegas menghukum pelanggaran terhadap kapal asing yang masuk ke perairan Indonesia secara ilegal dengan menenggelamkan kapal tersebut. Dua aspek tersebut, diupayakan Jokowi melalui sinergitas strategi ekonmomi dan keamanan dalam kebijakan Poros Maritim dunia.

\section{Poros Maritim Dunia : Strategi Peningkatan Sektor Ekonomi Indonesia}

Doktrin Poros Maritim merupakan upaya mempromosikan peran ekonomi maritim dan sinergi pembangunan kelautan nasional dengan target pembangunan ekonomi yang implementasinya termuat dalam pembangunan tol laut. Tol laut adalah upaya untuk menciptakan konektivitas laut yang efektif berupa adanya kapal yang berlayar secara rutin dan terjadwal dari wilayah barat sampai ke timur Indonesia (Prihartono, 2015). Secara sederhana, konsep tol laut menghubungkan koneksi antar pulau dan membantu akses niaga serta industrialisasi guna meningkatkan kesejahteraan rakyat dan ekonomi negara. Konsep tol laut diimplementasikan juga sebagai peningkatan kinerja transpor $\neg$ tasi laut melalui perbaikan jaringan pelayaran domestik dan internasional, penurunan dwelling time sebagai penghambat kinerja pelabuhan nasional, serta peningkatan peran transportasi laut. Dengan subsidi dan pembangunan tol laut diharapkan bisa mengembangkan perekonomian, pertahanan dan kesatuan wilayah perairan Indonesia.

Ide tol laut merupakan konsep untuk memperkuat jalur pelayaran yang dititkberatkan pada Indonesia bagian Timur. Upaya untuk mengkoneksikan jalur pelayaran tersebut akan mempermudah akses niaga tidak hanya bagi daerah kawasan timur Indonesia saja tetapi pada akhirnya juga membuka akses regional dari negara-negara Pasifik bagian selatan menuju negara-negara Asia di bagian timur. Realisasi ide tersebut dimulai dengan pembaharuan dan pemeliharaan infrastruktur pelabuhan, baik dalam skala nasional maupun internasional (Bappenas, 2015). Selama ini, kinerja pelabuhan-pelabuhan di Indonesia masih dalam kategori yang tidak terlalu baik dikarenakan kendala keuangan dalam perbaikan infrastruktur. Banyak pelabuhan yang tidak sesuai dengan standar internasional dan hal tersebut telah menghambat perdagangan maritim baik secara internal maupun eksternal. Berdasarkan laporan World Bank Logistics Performance Index, menyatakan Indonesia berada di peringkat 53, dibelakang Singapura, 
Malaysia, Thailand dan Vietnam dalam hal kinerja logistik dan pengiriman barang internasional negara-negara di dunia (Van Dijk et al., 2015: 10).

Pembaharuan infrastruktur pelabuhan yang dilakukan ini merupakan usaha untuk mengakomodir dan menyediakan sistem dan layanan kepelabuhan internasional, sehingga Indonesia bisa mengambil keuntungan ekonomi dalam distribusi logistik internasional. Transportasi laut saat ini digunakan oleh sekitar $90 \%$ perdagangan do $\neg$ mestik dan internasional sehingga pengembangan kapasitas dan konektivitas dari pelabuhan sangat penting untuk penurunan biaya logistik dan pemerataan pertumbuhan ekonomi nasional (Bappenas, 2015). Selama ini, selain tingginya biaya ekonomi, kurangnya fasilitas prasarana bongkar muat di pelabuhan, masih menjadi kendala sehingga menyebabkan turunnya minat penggunaan transportasi laut. Dari aspek logistik untuk angkutan laut, dapat dilihat juga terdapat banyak inefesiensi pengangkutan barang terutama untuk angkutan laut ke Indonesia bagian timur. Angkutan logistik laut dari Jawa ke Papua selalu terisi penuh, namun kembali dalam keadaan kosong. Tidak efisiennya konektivitas barang tersebut menyebabkan disparitas harga kebutuhan pokok antara Jawa dan Indonesia Timur, khususnya Papua sangat tinggi (Bappenas, 2015).

Peran transportasi laut melalui tol laut merupakan program pemerintah untuk memberikan kepastian kapal datang dan berangkat sesuai jadwal secara teratur dengan ada atau tidak adanya barang, kapal harus tetap berangkat. Rute yang dikembangkan dalam program tol laut bukanlah rute favorit domestik selama ini, karena feri komersial masih banyak yang belum aktif dalam jalur pelayaran ke daerah timur Indonesia. Operator kapal yakni PT. Pelni tidak akan rugi karena pemerintah telah menyiapkan Public Service Obligation (PSO) untuk menutupi biaya operasional jika kapal kargo sepi (Mandi, 2017). Oleh karena itu, melalui tol laut pusat pertumbuhan daerah tertinggal, serta pembangunan transportasi intrapulau dan antarpulau dapat diperbaiki sehingga menunjang pemerataan ekonomi diseluruh kawasan Indonesia..

Upaya pemerintah untuk lebih memperhatikan infrastruktur timur Indonesia dan efektivitas pembangunan pelabuhan kini mulai terlihat. Kemenhub telah merampungkan pembangunan fasilitas pelabuhan di 91 pelabuhan di seluruh Indonesia. 80 lokasi pembangunan pelabuhan tersebar di wilayah timur Indonesia dan 11 lokasi pelabuhan tersebar di wilayah barat Indonesia. Pada tahun 2016, terdapat 21 pelabuhan baru di Maluku dengan perincian 8 pelabuhan di Provinsi Maluku serta 13 pelabuhan di Maluku Utara๑. Pelabuhan Wasior di Kabupaten Teluk Wondama, Papua juga telah resmi dibuka dan digunakan untuk memperlancar transportasi laut Indonesia. Sebagai tindak lanjut rangkaian kegiatan peresmian 91 infrastruktur pelabuhan tersebut, sebanyak 55 pelabuhan diresmikan dalam 
kurun waktu April hingga Juni tahun 2016. Pembangunan infrastruktur pelabuhan ini telah mengacu pada sistem pembangunan transportasi nasional, lokal dan kewilayahan dengan tetap mengutamakan keselamatan dan keamanan transportasi laut (Liputan 6, 2016).

Selain itu, pemerintah juga mengembalikan sistem jadwal kapal yang teratur (regular shipping) ke Indonesia Timur yang sebelumnya sempat dihapuskan. Keteraturan tentang jadwal keberangkatan kapal tidak hanya memudahkan para pengusaha besar untuk menentukan kiriman logistik barang tetapi juga memudahkan pedagang dan petani kecil untuk membawa barangnya keluar daerah (Sindonews, 2016). Untuk mewujudkan pemerataan, juga diperlukan pembangunan den $\neg$ gan konsep ship promote the trade, dimana pembangunan konektivitas di wilayah timur Indonesia diharapkan mampu meningkatkan aktivitas ekonomi dan perdagangannya. Pengembangan pelayanan transportasi laut sebagai tulang pung $\neg$ gung distribusi logistik yang menghubungkan wilayah Barat dan Timur Indonesia diharapkan mampu mempercepat pertum $\neg$ buhan ekonomi disertai terwujudnya pemerataan (Bappenas, 2015).

Banyaknya pembangunan pelabuhan tersebutkinitelahmenyebabkan disparitas harga kebutuhan pokok menurun. Berdasarkan data statistik dari Kementerian Koordinator Bidang Maritim, disparitas harga sudah turun lumayan besar, sekitar 30\% sampai 40\% pada tahun 2016 (Republika, 2017). Upaya cepat pemerintah dalam melaksanakan pembangunan tol laut diharapkan bisa terwujud melalui pembangunan pelabuhan. Dalam tempo tiga tahun sejak tahun 2014 sampai tahun 2016, Pemerintahan Jokowi telah membangun 150 pelabuhan besar dan kecil yang tersebar di seluruh wilayah Indonesia khususnya di daerah Indonesia Timur. Selain itu, juga terdapat enam rute kapal terjadwal yang melayani 24 simpul pelayaran tol laut. Meskipun dalam beberapa tahun terakhir proyek tol laut masih ditemukan beberapa kendala dan harus dievaluasi, terutama dalam hal desain rute tol laut, ukuran kapal logistik dan efektifitas pelayaran nasional. Ukuran kapal-kapal yang melayani simpul-simpul tol laut tersebut masih belum sesuai dengan arus logistik dan jumlah penumpang. Selain itu, sebagian rute-rute tersebut melewati jalur yang dilalui perusahaan swasta, sehingga menjadi tidak efisien (Berita Satu, 2016).

Sebagai upaya evaluasi tersebut, pemerintah telah melakukan pembatasan masuknya kapal-kapal asing kedalam perairan Indonesia dengan menyediakan dua pelabuhan internasional yaitu Kuala Tanjung dan Bitung. Dua pelabuhan internasional tersebut akan menjadi ruang tamu bagi kapal-kapal asing dari berbagai negara. Terbukanya akses regional melalui implementasi konsep tol laut dapat memberikan peluang industri kargo dan logistik nasional untuk berperan da $\neg$ lam distribusi internasional. Dengan posisi pelabuhan internasional di wilayah terdepan 
Indonesia maka kapal yang melakukan ekspor dan impor barang akan berlabuh di wilayah pinggiran Indonesia. Untuk melᄀanjutkan distribusi logistik kedalam wilayah akan tetap menggunakan kapal lokal Indo $\neg$ nesia. Dengan penyediakan dua pelabuhan internasional, pengawasan kapalkapal asing yang masuk ke Indonesia juga menjadi mudah untuk diidentifikasi. Dengan pembatasan ini diharapkan bisa menjadi sarana pemudahan kontrol Angkatan Laut dan Bakamla dalam hal pengawasan keamanan laut. Strategi ini juga tidak hanya meminimalisir pergerakan kapal dagang internasional yang saat ini masih sangat banyak didominasi kapal berbendera asing di wilayah dalam Indo-nesia tetapi juga dapat meminimalisir penetrasi produk asing hingga wilayah dalam Indone $\neg$ sia. Kontrol keamanan yang dilakukan otomatis menjadi lebih mudah. Upaya ini merupakan sinergi antara kebijakan ekonomi sekaligus memuat aspek pertahanan dan keamanan didalamnya.

Selain dua pelabuhan internasional, pemerintah juga menyiapkan enam pelabuhan utama yaitu Pelabuhan Belawan, Tanjung Priok, Tanjung Perak, Makassar dan Sorong. Berbagai pembenahan dan pengembangan pelabuhan-pelabuhan tersebut juga harus diikuti dengan pembangunan sarana prasarana keamanan dan modernisasi peralatan militer didalamnya (Kadar, 2015). Melalui implementasi yang dikembangkan dalam konsep tol laut, maka akan tercipta keunggulan kompetitif bangsa dan penguatan industri nasional disertai pemer $\neg$ ataan dan disparitas harga yang rendah di seluruh wilayah nusantara. Selain perbaikan dan perhatian terhadap pengembangan pelabuhan dan transportasi laut, untuk mendorong kegiatan maritim Indonesia menjadi lebih modern dan mudah digunakan oleh masyarakat diharapkan juga peran pemerintah dari sisi pertahanan dan penguasaan laut sehingga Indonesia mampu menjamin penggunaan laut untuk kepentingan nasional. Penyelesaikan permasalahan batas wilayah laut juga menjadi penting untuk diselesaikan agar dapat memberikan kepastian hukum atas batas wilayah negara. Dengan penyelesaian masalah pertahanan dan perbatasan diharapkan Indonesia dapat mempererat hubungan bilateral serta mendorong kerjasama perbatasan antarnegara termasuk dalam pengelolaan kawasan maritim (Hardiana \& Trixie, 2014).

Implementasi tol laut selain sebagai penyediaan infrastruktur pelabuhan, juga harus dilengkapi dengan modernisasi sistem navigasi dan prasarana patroli laut. Kondisi inilah yang menjadi alasan bagi pemerintah untuk memperkuat industri pertahanan dalam negeri. Dari kegiatan terkait industri pertahanan maritim ini, konsep Poros Maritim Indonesia diharapkan dapat merangsang perekonomian domestik Indonesia. Oleh karenanya selaras dengan uraian di atas, pembangunan sistem pertahanan akan menjadi peranan kunci dalam menjadikan program Poros Maritim bersifat ekonomis, artinya terdapat banyak efiensi penggunaan transportasi dan infrastruktur laut yang aman. 


\section{Poros Maritim Dunia: Strategi Peningkatan Keamanan Laut Indonesia}

Wilayah maritim merupakan urat nadi utama interaksi kepentingan global, sehingga menjadikan keamanan maritim isu yang bagi krusial bagi banyak negara di dunia tidak hanya dilihat dari kepentingan ekonomi saja tetapi juga kepentingan pertahanan. Stabilitas maritim sangat diperlukan dalam rangka menjaga kepentingan dan pertumbuhan ekonomi, sekaligus juga menjadi sumber keamanan. Kondisi geografis yang berupa kepulauan dan berbatasan langsung dengan sejumlah negara mengakibatkan banyaknya ancaman yang harus dihadapi Indonesia. Secara umum ancaman tersebut terdiri dari beberapa hal. Pertama, ancaman sengketa perbatasan maritim. Sengketa teritorial Laut Cina Selatan merupakan permasalahan perbatasan yang hingga kini masih belum selesai. Sengketa teritorial tersebut melibatkan tidak hanya Indonesia tetapi juga negara-negara lain di Asia Tenggara, yaitu Malaysia, Vietnam, Filipina dan Brunei Darussalam.

Kondisi ini tentu mengkhawatirkan bagi kawasan, posisi strategis maritim Indonesia sangat penting dan berpengaruh dalam peta konflik perbatasan ASEAN. Dua pertiga dari seluruh luas perairan Asia Tenggara adalah perairan yurisdiksi Indonesia. Melihat keadaan tersebut, tentu Indonesia akan selalu memainkan peran sentral dalam keamanan dan stabilitas regional (Leong et al., 2005). Kerentanan akan kedaulatan teritorial Indonesia tersebut kemudian diperparah oleh perselisihan mengenai klaim atas pulau-pulau, oleh negara tetangga, khususnya Malaysia. Kondisi demikian harus disiasati oleh pemerintah untuk menghindari disintegrasi bangsa seperti lepasnya Pulau Sipadan dan Ligitan (Sambhi in Chen et al, 2014: 39). Melindungi kedaulatan teritorial merupakan prioritas utama Indonesia. Untuk itu, Pemerintahan Jokowi bertekad untuk menegakkan kedaulatan teritorial terhadap setiap gangguan dan mengintensifkan upaya diplomasi untuk menyelesaikan masalah perbatasan dengan negaranegara tetangga. Masalah perbatasan wilayah dengan negara sekitar begitu penting sehingga pemerintah perlu membahasnya sebagai agenda khusus dan mencarikan solusi penyelesaiannya.

Kepentingan negara-negara luar kawasan atas wilayah perairan Asia Tenggara juga perlu menjadi perhatian. Kepentingan utama bagi negaranegara luar kawasan, terutama dari negara-negara besar yaitu Cina, Jepang dan Amerika Serikat, adalah kemudahan akses maritim dan ketersediaan sumber daya bagi kepentingan geoekonomi negara-negara tersebut. Posisi strategis Indonesia termasuk di dalamnya Alur Laut Kepulauan Indonesia (ALKI), dapat memudahkan dan meringankan peredaran logistik perdagangan antar benua yang dilakukan oleh negara-negara besar tersebut. Paradigma geostrategis ini berperan penting dalam interaksi keamanan antar kawasan di benua Asia dan Australia. Kepentingan negara-negara luar kawasan terhadap perairan Indonesia tersebut harus diantisipasi dan direspons dengan tepat oleh Indonesia (Hardiana \& Trixie, 2014). 
Permasalahan keamanan maritim kedua yang juga perlu mendapat perhatian adalah ancaman-ancaman yang bersifat non-tradisional, diantaranya adalah pembajakan terorisme maritim dan separatisme. Kerusuhan sosial antarpengguna laut, perompakan dan pembajakan, imigran dan pembalakan ilegal, serta penyelundupan juga menjadi masalah yang perlu segera diselesaikan. Semakin banyak kapal-kapal internasional yang melewati perairan Indonesia memungkinkan terjadinya kejahatan pembajakan maritim. Fenomena ini tidak hanya dinilai sebagai bentuk kerentanan dari aspek keamanan saja tetapi juga kerugian ekonominya sangat besar. Meskipun pembajakan dan terorisme maritim belum menjadi ancaman utama saat ini tetapi potensi tersebut harus bisa diantisipasi dengan baik sebelum menjadi ancaman nasional. Transportasi laut yang masih menjadi jalur utama lalu lintas perdagangan global, juga memiliki potensi penyeludupan barang. Pada saat yang bersamaan, aktivitas penyelundupan senjata api ilegal, narkoba, bahan bakar minyak, hingga manusia juga mudah terjadi dan dapat menjadi ancaman serius bagi keamanan (Muhammad, 2014).

Ancaman yang ketiga adalah penangkapan ikan secara ilegal (illegal fishing). Menurut data tahun 2014, dari Kementrian Kelautan dan Perikanan, nilai potensi kekayaan sumber daya alam yang terdapat pada sektor kelautan dan perikanan diproyeksikan mencapai US\$ 171 miliar per tahun. Secara lebih terperinci, nilai potensi tersebut meliputi sektor perikanan $\$ 32$ miliar, wilayah pesisir $\$ 56$ miliar, bioteknologi $\$ 40$ miliar, wisata bahari $\$ 2$ miliar, minyak bumi \$21 miliar dan transportasi laut sebesar \$20 miliar. Besarnya potensi tersebut ditengah keterbatasan pengawasan aparat dan armada kapal patroli menjadikan perairan Indonesia menjadi daya tarik tersendiri bagi pihak-pihak asing untuk melakukan penangkapan ikan secara ilegal. Perairan Indonesia yang rawan dari ancaman kegiatan illegal fishing tersebut menyebar mulai dari perairan Laut Natuna, Laut Sulawesi, Laut Aceh, Samudera Hindia bagian selatan, Laut Aru, hingga Laut Arafura di sekitar Papua.

Gagasan Poros Maritim bisa dibangun melalui konsepsi yang kuat dan implementatif secara ekonomi dan keamanan. Ekonomi dan keamanan harus saling menguatkan. Sangat sulit melaksanakan kegiatan perdagangan di sektor maritim apabila kondisi maritimnya tidak aman. Peranan penting keamanan dalam menunjang kesejahteraan ekonomi dan perdagangan telah menjadi syarat mutlak bagi negara yang ingin memajukan sektor maritimnya. Penculikan WNI di Laut Sulu oleh kelompok Abu Sayyaf dan munculnya ISIS di Marawi merupakan contoh bahwa ketidakamanan sektor kelautan akan berdampak pada perniagaan distribusi barang dan jasa yang melibatkan laut sebagai sarana transportasinya. Hal ini akan menjadi ancaman serius tidak hanya bagi Indonesia tetapi juga negara- 
negara di kawasan ASEAN pada umumnya (Sutisna, 2017).

Masalah perbatasan darat dan laut yang selama ini belum tuntas juga mengakibatkan perekonomian Indonesia menjadi sulit berkembang. Selama ini, orientasi pembangunan nasional merupakan orientasi land based development sehingga laut hanya sebagai tempat eksploitasi dan eksplorasi sumber daya alam, pembuangan limbah dan kegiatan ilegal seperti penyeludupan. Kondisi ini diperparah dengan kebijakan pembangunan kelautan yang dilakukan secara parsial dan tidak komprehensif. Masingmasing kementerian dan lembaga menjalankan program pembangunannya secara parsial, belum terintegrasi dan belum terkonsentrasi dalam pembangunan kelautan (Kartika, 2014).

Oleh karena itu, presiden Jokowi melalui Kementrian Kelautan dan Perikanan, berupaya memerangi kegiatan illegal fishing di perairan Indonesia. Dalam hal ini, tentu peran pemerintah dibutuhkan untuk bisa menjaga dan mempertahankan serta mengolah kekayaan dan potensi maritim di Indonesia. Untuk mengolah sumber daya alam laut, diperlukan modernisasi teknologi dan pendanaan yang berkesinambungan dari negara agar bisa memberikan keuntungan tidak hanya dari sisi ekonomi tetapi juga keamanan maritim. Kegiatan memerangi illegal fishing tersebut diwujudkan melalui pembakaran dan penembakan kapal-kapal laut asing yang masuk ke Indonesia secara ilegal. Kebijakan penembakan kapal ini merupakan strategi Jokowi dalam memberikan efek jera dan penggetar (deterrence) terhadap negara lain. Efek penggetar juga sekaligus menjadi sinyal ancaman yang berfungsi sebagai strategi pencegah untuk meyakinkan target bahwa Indonesia secara serius menegakkan kedaulatan teritorialnya dengan melakukan pembakaran dan penembakan kapal asing sehingga diharapkan memberikan efek jera dalam kegiatan illegal fishing (Nugraha et al, 2016). Maraknya kegiatan Illegal Unreported and Unregulated (IUU) Fishing yang terjadi di Indonesia semakin merugikan Indonesia. Kerugian tersebut berdampak pada ancaman mengancam kelestarian sumber daya kelautan dan perikanan dimasa yang akan datang.

Sebagai implementasi untuk mensinergikan ekonomi dan keamanan, pemerintah juga telah mensahkan RUU Kelautan menjadi UU Kelautan. UU Kelautan akan menjadi payung hukum untuk mengatur pemanfaatan dan kegiatan kelautan Indonesia secara komprehensif dan terintegrasi sesuai dengan peraturan nasional Indonesia (Hardiana \& Trixie, 2014). Selain dengan peraturan undang-undang, Jokowi juga menunjuk Kementrian Koordinator Maritim sebagai lembaga untuk mengintegrasikan persoalanpersoalan maritim serta solusinya dan mensosialisasikan kepada masyarakat di wilayah pesisir Indonesia sebagai pelaksana pertama terhadap hal-hal yang terjadi di lautan Indonesia. Secara umum, Kementerian Koordinator Maritim tidak hanya akan menangani persoalan perikanan dan sumber daya 
maritim, namun juga keamanan, batas wilayah laut, bea cukai dan banyak hal lain yang selama ini menjadi tanggung jawab sejumlah kementerian lain (Tabloid Diplomasi, 2015).

Sinergitas strategi ini berupaya mengorganisasikan kapabilitas nasional yang ditujukan pada pemberantasan kegiatan illegal fishing sehingga diharapkan Indonesia mendapatkan keuntungan tidak hanya dari sisi ekonomi pemberdayaan kelautan tetapi juga kepentingan keamanan maritimnya dapat dicapai. Untuk jangka panjang, strategi ini dinilai akan berjalan efektif dan efisien untuk mencapai kepentingan nasional. Kebijakan pembangunan sektor keamanan tersebut diarahkan menuju pengembangan perekonomian maritim yang terintegrasi dengan pembangunan daerah timur Indonesia. Melalui integrasi ini, diharapkan pembangunan maritim pada akhirnya membantu peningkatan pada aktivitas perekonomian yang berkembang di wilayah darat Indonesia (Paskarina, 2014).

Indonesia selain membangun kapasitas pengelolaan maritim secara mandiri juga harus mencari kemitraan dengan negara lain yang terlibat dalam penangkapan ikan ilegal. Langkah pertama yang dilakukan adalah skema kerja sama bilateral. Pada April 2015, Thailand dan Indonesia bersama-sama mengumumkan pembentukan kelompok kerja untuk menangani praktik penangkapan ikan secara ilegal. Kerja sama ini perlu disempurnakan dan dilanjutkan dalam jangka panjang agar lebih efektif. Langkah yang juga penting dilakukan adalah kerja sama perikanan dalam agenda ASEAN. Guna mengatasi persoalan tersebut beberapa kerja sama keamanan maritim regional dilakukan seperti ASEAN-US Meeting on Anti-Piracy and Counter-Terrorism, ASEAN Maritime Forum, ASEAN-Japan Maritime Port and Transport Security. Selain itu kerja sama antarkawasan juga telah dilakukan seperti ASEAN-EU Experts Meeting on Maritime Security. Ini adalah kesempatan untuk mengatasi permasalahan di balik penangkapan ikan ilegal dan permasalahan keamanan secara lebih luas karena melibatkan organisasi kawasan (Junttila, 2014).

Isu keamanan menjadi hal penting yang turut menguatkan kembalinya wacana negara maritim. Tidak tergalinya potensi maritim secara ekonomi menegaskan bahwa infrastruktur pertahanan maritim Indonesia sangat lemah. Perubahan global memandang pentingnya jalur perdagangan maritim maka isu keamanan menjadi penting bagi Indonesia tidak hanya untuk mempertahankan kedaulatannya di laut saja tetapi juga memberikan jaminan keamanan bagi kapal-kapal logistik international yang melewati perairan Indonesia. Kondisi ini membangkitkan kesadaran bahwa masih terdapat banyak anomali dalam kebijakan pertahanan Indonesia yang selama ini terlalu berorientasi pada penguatan sistem militer di darat saja dan mengesampingkan pengembangan postur kebijakan maritim. Padahal bentuk wilayah Indonesia adalah negara kepulauan dan memiliki banyak 
selat strategis dalam pelayaran internasional (Paskarina, 2016).

Pada waktu Indonesia dipimpin oleh presiden Susilo Bambang Yudhoyono, permasalahan maritim menghadapi beberapa tantangan, seperti sumber daya yang terbatas, infrastruktur yang kurang lengkap dan fasilitas penelitian pertahanan yang sangat minim. Akibatnya, modernisasi peralatan angkatan laut yang berteknologi tinggi sangat sulit untuk dikembangkan. Pada masa Jokowi, salah satu pilihannya adalah menarik investasi asing masuk ke Indonesia untuk membiayai kebutuhan industri pertahanan dan infrastruktur maritim. Pemerintah Indonesia selama ini hanya mampu mendanai sekitar 30\% dari keseluruhan biaya infrastruktur yang dibutuhkan. Untuk $70 \%$ dana lainnya, pemerintah melakukan pembiayaan dengan bantuan investasi swasta atau lembaga keuangan internasional (Percival, 2015).

Strategi pengembangan infrastruktur melalui pembiayaan swasta tersebut diwujudkan melalui pembangunan tol laut serta pemberantasan illegal fishing. Upaya ini merupakan wujud dari sebuah kesadaran bahwa kemakmuran dan masa depan bangsa sangat ditentukan oleh pengelolaan sumber daya kelautan. Tujuan akhir dari kesadaran ini adalah perwujudan gagasan Poros Maritim dunia yang memunculkan konstruksi baru tentang jatidiri bangsa yang dikaitkan dengan kesejahteraan masyarakat dan kemakmuran serta kebangaan sebagai negara maritim yang mampu menjaga kedaulatan teritorialnya (Paskarina, 2016).

Mempertahankan dan memperjuangkan hal tersebut tidak hanya sekedar dengan pendekatan keamanan, tapi juga dengan menghadirkan 'kesejahteraan' negara disana. Dengan kesejahteraan dan kemakmuran ekonomi, jaminan keamanan di wilayah perairan akan dapat dicapai. Indonesia menjadi sangat mungkin menjadi negara Poros Maritim dunia apabila elemen-elemen penting tersebut dapat berjalan secara sinergis. Indonesia sampai saat ini masih belum mampu mencapai prestasi ekonomi yang stabil karena terdapat banyak permasalahan infrastruktur dan sistem keamanan yang masih belum dibenahi. Akibatnya biaya produksi dan ongkos logistik barang menjadi sangat tinggi. Padahal ongkos logistik memiliki kontribusi hingga 30\% dari total biaya produksi. Sebagai contoh implikasi dari lemahnya sistem ini adalah biaya pengiriman barang impor dari Cina ke Indonesia lebih murah daripada ongkos biaya pengiriman barang dari pulau Jawa menuju Papua (Kadar, 2015). Penguasaan laut menjadi faktor penting dalam kemajuan ekonomi suatu negara. Gagasan mengenai perlunya keamanan di dalam domain maritim guna menjamin kelancaran perdagangan internasional memiliki kesamaan dengan fenomena globalisasi dan regionalisasi ekonomi abad ke-21 yang dilakukan tidak hanya Indonesia tetapi juga Amerika Serikat dan juga Cina (Wardhana, 2016). 
Strategisnya posisi Indonesia secara geopolitik harus didukung dengan kemampuan untuk menjaga kedaulatan terhadap wilayah NKRI, khususnya daerah perbatasan maritim. Kawasan perbatasan harus dapat dijaga melalui kekuatan maritim yang unggul. Selain itu, negarajuga mampu menghadapi ancaman internal dan eksternal melalui kelompok terorisme atau kelompok kejahatan lainnya. Kemampuan menghadapi ancamanancaman internal dan eksternal tersebutlah yang membuat Indonesia akan disegani secara global dan diakui sebagai Poros Maritim dunia. Kekuatan maritim merupakan simbiosis antara industri dalam negeri (ekonomi) dan kemampuan angkatan laut sebagai pelindung wilayah teritorial Indonesia (keamanan). Moderniasasi sistem persenjataan mutlak menjadi sangat diperlukan sebagai upaya untuk mengamankan sumber daya laut dan menjamin arus pelayaran internasional dapat berjalan dengan aman (Kadar, 2015). Selain itu, dengan keamanan maritim yang unggul bisa meminimalisir risiko dan permasalahan maritim serta melindungi warga dan kepentingan nasional. Kemampuan negara dalam mengelola ekonomi dan keamanan akan menjadi parameter kunci keberhasilan sebuah negara untuk menjalankan good maritime governance.

\section{Kesimpulan}

Pengejawantahan dua kepentingan strategis bangsa yaitu ekonomi dan keamanan diwujudkan melalui doktrin kebijakan Poros Maritim Jokowi. Ekonomi dan keamanan pada dasarnya seperti dua sisi mata uang. Pembangunan ekonomi membutuhkan stabilitas pertahanan dan keamanan, sedangkan kekuatan pertahanan membutuhkan alokasi anggaran dan kemampuan ekonomi yang mendukung. Pembagian alokasi anggaran pertahanan sangat dipengaruhi oleh besarnya pendapatan suatu negara. Sementara pendapatan suatu negara, merupakan refleksi dari kemampuan negara tersebut untuk melindungi dan memanfaatkan sumber daya alam yang ia miliki dengan kekuatan pertahanan dan teknologi yang unggul. Sinergitas pembangunan aspek ekonomi dan keamanan yang dilakukan dalam kebijakan Poros Maritim dunia sudah berjalan dengan baik meskipun masih banyak permasalahan kemanan yang perlu untuk diperhatikan, khususnya permasalhan ancaman sengketa perbatasan, koordinasi antarlembaga dan kementrian, permasalahan modernisasi sistem pertahanan dan peningkatan teknologi maritim yang pada akhirnya juga mendukung kemampuan untuk mengamankan perairan teritorial Indonesia.

Masa depan industri kemaritiman Indonesia disamping sebagai doktrin pertahanan nasional juga sebagai dimensi pendukung diplomasi maritim Indonesia secara lebih luas di masa yang akan datang. Sinergi antara aspek ekonomi dan keamanan sangat penting untuk dilaksanakan 
dalam gagasan Poros Maritim sehingga pada akhirnya akan menunjang kemampuan Indonesia sebagai Poros Maritime global. Apabila sinergi ini berhasil dilakukan, maka Jokowi telah merubah doktrin dasar politik luar negeri Indonesia. Politik luar negeri Indonesia selama ini memiliki keyakinan untuk selalu mendayung diantara dua karang, ketika masa Jokowi dengan kebijakan Poros Maritimnya, doktrin tersebut telah berganti menjadi sekali dayung dua tiga pulau terlampaui.

\section{Daftar Pustaka}

Adelle, N. (2014) Jokowi Spells Out Vision For Indonesia's (Online), Centre for Strategic and International Studies, 26 November. Tersedia di $<$ http://csis.org/publication/southeastasia-scott-circle-jokowi-spellsoutvision-indonesias-global-maritimenexus> [Diakses 2 November 2017].

Agastia, G.B.D \& Perwita, A.A.B. (2015). Jokowi's Maritime Axis: Change and Continuity of Indonesia's Role in Indo-Pacific. Journal of ASEAN Studies 3(1), pp. 32-41.

Bakrie, C.R. (2015) Poros Maritim dalam Perspektif Geostrategi, Geopolitik dan Geoekonomi (Online). Tabloid Diplomasi, 4 Oktober. Tersedia di: $\quad<$ http://www.tabloiddiplomasi.org/index.php/2015/10/04/ poros-maritim-dalam-perspektif-geostrategi-geopolitik-dangeoekonomi/> [Diakses 5 November 2017].

Bappenas (2015) Laporan Implementasi Konsep Tol Laut 2015-2019. Jakarta: Direktorat Transportasi Bappenas.

Berita Satu (2016) Tol Laut, Strategi Jokowi Wujudkan Indonesia Sebagai Poros Maritim Dunia (Online). Tersedia di: <http://www.beritasatu. tv/news/tol-laut-strategi-jokowi-wujudkan-indonesia-sebagaiporos-maritim- dunia/> [Diakses 2 Oktober 2017].

Chen, J. et.al. (2014) New Perspectives on Indonesia: Understanding Australia's Closest Asian Neighbour. Perth: Perth USAsia Centre.

Dijk, C.V., De Mheen, P.V \& Bloem, M. (2015). Indonesia Maritime Hotspot. Den Haag: Maritime by Holland.

Fajriah, L.R. (2016) Rizal Ramli Beberkan Hasil Pembangunan Poros Maritim Jokowi (Online). Sindonews, 29 Maret. Tersedia di: <https:// ekbis.sindonews.com/read/1096673/34/rizal-ramli-beberkan-hasilpembangunan-poros-maritim-jokowi-1459257112> [Diakses 28 November 2017).

Gindarsah, I. (2014). Politics, Security and Defence in Indonesia: Interactions and Interdependencies. National Security College Issue Brief, May 4, pp. 25-32.

Hardiana, I. \& Trixie, B. (2014). Potensi Indonesia sebagai Negara Maritim (Online). Sekretariat Kabinet RI, 21 Oktober. Tersedia di: $<\mathrm{http}: / /$ setkab. 
go.id/menuju-indonesia-sebagai-negara-poros-maritim/> [Diakses 7 November 2017].

Junttila, K. \& Weatherby, C. (2014) Indonesia's Global Maritime Nexus: Implications for Illegal Fishing (Online). Stimson, 19 September. Tersedia di: <https://www.stimson.org/content/indonesias- weatherforecast-hazy-with-a-chance-of-clear-skies> [Diakses 14 November 2017].

Kadar, A. (2015). Pengelolaan Kemaritiman Menuju Indonesia sebagai Poros Maritim Dunia. Jurnal Keamanan Nasional 1(3), pp. 438-439.

Kartika, S.D. (2014). Keamanan Maritim Dari Aspek Regulasi dan Penegakan Hukum. Jurnal Negara Hukum 5(2), pp. 1-19.

Leong, H. K., \& Ku, S. C. (2005). China and Southeast Asia: Global Changes and Regional Challenges. Singapore: ISEAS.

Liputan 6. (2016). Kemenhub Resmikan 21 Pelabuhan di Maluku (Online). Tersedia di: <http://bisnis.liputan6.com/read/2518935/kemenhubresmikan-21-pelabuhan-di-maluku> [Diakses 7 November 2017].

Mandi, N.B.R. (2017). Development of Ferry Port as a Complement of "Tol Laut": Case Study on Ferry Port of Ketapang. International Refereed Journal of Engineering and Science 6(3), pp. 31-37.

Muhamad, S.V. (2014). Indonesia Menuju Poros Maritim Dunia. Info Singkat Hubungan Internasional 6(21), pp. 5-8.

Nugraha, M.H.R. \& Sudirman, A. (2016). Maritime Diplomacy Sebagai Strategi Pembangunan Keamanan Maritim Indonesia. Jurnal Wacana Politik 1(2), pp. 175-182.

Paskarina, C. (2016). Wacana Negara Maritim dan Reimajinasi Nasionalisme Indonesia. Jurnal Wacana Politik 1(1), pp 1-18.

Percival, B. (2015). Indonesia's New Maritime Ambitions: Implications for U.S.-Indonesian Engagement. Tersedia di: <http://www.dtic.mil/ dtic/tr/fulltext/u2/1014572.pdf $>$ [Diakses 7 November 2017].

Presiden RI (2015) Indonesia Sebagai Poros Maritim Dunia (Online). Tersedia di: <http://www.presidenri.go.id/berita-aktual/indonesiasebagai-poros-maritim-dunia.html> [Diakses 1 Desember 2017).

Prihartono, B. (2016) Pengembangan Tol Laut dalam RPJMN 2015-2019 dan Implementasi 2015 (Online), Bappenas. Tersedia di <http://www. bappenas.go.id/files/Pengembangan\%20Tol\%20Laut\% 20Dalam\%20 RPJMN\%202015-2019\%20Dan\%20Implementasi\%202015.pdf> [Diakses 7 November 2017].

Republika (2017) Rizal Ramli: Poros Maritim Jokowi Bukan Mimpi, Sudah Terasa Dampak Positifnya (Online). Tersedia di: <http://politik.rmol. co/read/2017/08/27/304660/Rizal-Ramli:-Poros-Maritim-JokowiBukan-Mimpi,-Sudah-Terasa-Dampak-Positifnya-> [Diakses 2 Oktober 2017). 
Sukma, R. (2014) Gagasan Poros Maritim (Online), Centre of Strategic and International Studies, 21 Agustus. Tersedia di: <https://www.csis. or.id/publications/page/gagasan_poros_maritim.html> [Diakses 29 November 2017).

Sutisna, M. (2017) Visi Poros Maritim: Mimpi, Cita-Cita dan Realitanya (Online). Monitor, 24 Agustus. Tersedia di: <http://monitor. co.id/berita/3153/opini-visi-poros-maritim-mimpi-cita-cita-danrealitanya> [Diakses 4 November 2017].

Wardhana, W. (2016). Poros Maritim: Dalam Kerangka Sejarah Maritim Dan Ekonomi Pertahanan. Jurnal Masyarakat E Budaya 18(3), pp. 359-375. 